\title{
Folates provoke cellular efflux and drug resistance of substrates of the multidrug resistance protein 1 (MRP1)
}

\author{
Jan Hendrik Hooijberg • Gerrit Jansen • Ietje Kathmann • Rob Pieters • \\ Adrie C. Laan · Ina van Zantwijk · Gertjan J. L. Kaspers · Godefridus J. Peters
}

Received: 3 December 2013 / Accepted: 19 February 2014 / Published online: 5 March 2014

(C) Springer-Verlag Berlin Heidelberg 2014

\begin{abstract}
Cellular folate concentration was earlier reported to be a critical factor in the activity and expression of the multidrug resistance protein MRP1 (ABCC1). Since MRP1 mediates resistance to a variety of therapeutic drugs, we investigated whether the cellular folate concentration influences the MRP1-mediated cellular resistance against drugs. As a model system, we used the human ovarian carcinoma cell line $2008 \mathrm{wt}$, and its stably MRP1/ABCC1-transfected subline 2008/MRP1. These cell types have a moderate and high expression of MRP1, respectively. In folate-deprived 2008/MRP1 cells, the MRP1-mediated efflux of its model substrate calcein decreased to $\sim 55 \%$ of the initial efflux rate under folaterich conditions. In $2008 \mathrm{wt}$ cells, only a small decrease in efflux was observed. Folate depletion for 5-10 days markedly increased $(\sim 500 \%)$ cellular steady-state accumulation
\end{abstract}

\section{J. H. Hooijberg}

Department of Clinical Chemistry, Slotervaartziekenhuis

Amsterdam, Amsterdam, The Netherlands

J. H. Hooijberg · I. van Zantwijk · G. J. L. Kaspers

Department of Pediatric Hematology/Oncology, VU University

Medical Center (VUMC), Amsterdam, The Netherlands

G. Jansen

Department of Rheumatology, VU University Medical Center

(VUMC), Amsterdam, The Netherlands

I. Kathmann · A. C. Laan · G. J. Peters $(\bowtie)$

Department of Medical Oncology, VU University Medical Center

(VUMC), De Boelelaan 1117, 1007 MB Amsterdam,

The Netherlands

e-mail: gj.peters@vumc.nl

R. Pieters

Department of Pediatric Oncology, Sophia Children Hospital,

Rotterdam, The Netherlands of calcein in 2008/MRP1 cells and moderately in 2008wt cells. A subsequent short $(24 \mathrm{~h})$ exposure to $2.3 \mu \mathrm{M} \mathrm{L}-\mathrm{leu}-$ covorin decreased calcein levels again in MRP1-overexpressing cells. Folate deprivation markedly increased growth inhibitory effects of the established MRP1 substrates daunorubicin ( $\sim$ twofold), doxorubicin ( fivefold), and methotrexate ( $\sim 83$-fold) in MRP1-overexpressing cells, proportional to MRP1 expression. In conclusion, this study demonstrates that increased cellular folate concentrations induce MRP1/ABCC1-related drug efflux and drug resistance. These results have important implications in the understanding of the role of MRP1 and its homologs in clinical drug resistance.

Keywords MRP1 Folate $\cdot$ Methotrexate $\cdot$ Multidrug resistance $\cdot$ Anthracyclines $\cdot$ Calcein

\section{Introduction}

Folates are vitamins that are daily required for many biosynthetic processes. As one-carbon donors and cofactors, they play a role in the synthesis of amino acids (methionine, serine), de novo purine synthesis, and synthesis of thymidylate for DNA synthesis [1]. In addition, folates influence gene expression via DNA methylation, as a result of methionine production from homocysteine and methyltetrahydrofolate.

Folate supplementation to the diet was earlier reported to protect against cancer and other diseases [2-4]. Later, warnings were given that an abundant intake of folate might promote tumorigenesis of existing neoplasia $[5,6]$. Recently, however, meta-analyses indicated that folic acid supplementation does not affect incidence of site-specific cancer during the first years of folate treatment $[7,8]$. 
Folate supplementation has become an essential part of certain cancer chemotherapeutic regimens, since it reduces toxicity of antifolate-based treatments [9]. For instance, the folate leucovorin is commonly used to reduce antifolate toxicity in leukemias and several solid tumors $[9,10]$. Also, combination of the antifolate Alimta (pemetrexed) with cisplatin was less toxic after folic acid supplementation [11], and folic acid not only increased the efficacy of this combination, but also that of cisplatin as a single drug.

Nowadays, there is growing evidence that dietary supplements such as folic acid can mimic, intensify, or attenuate the effects of chemotherapeutic agents [12].

One mechanism by which folates might influence chemotherapy is via their interaction with transporter proteins that cause multiple drug resistance (MDR). We earlier demonstrated, for instance, that folates enhance the cellular efflux of the anticancer agent daunorubicin (DNR)-mediated by the multidrug resistance protein 1 (MRP1/ABCC1) [13]. MRP1 is the founding member of the C-subclass of ATP-binding cassette $(\mathrm{ABC})$ transporters. Most of the nine MRP/ABCC members are lipophilic anion pumps that transport a range of structurally unrelated therapeutic drugs and other xenobiotics, as well as several physiologically important organic anions such as leukotriene C(4) and prostaglandin E2 out of the cell [14-22]. Like other $\mathrm{ABC}$ transporters, such as $\mathrm{P}$-glycoprotein (P-gp/ABCB1) and the breast cancer resistance protein (BCRP/ABCG2), expression of MRPs in cancer cells can confer resistance to a broad variety of anticancer agents. For detailed information on MRP1 and its homologs, we refer to recent reviews $[21,22]$.

We and others reported that antifolates, including methotrexate (MTX), are good substrates of most MRPs [2026]. These agents are structural analogs of natural reduced folates and act as antagonists of cellular folate metabolism. MTX is used in the treatment of several types of cancer and inflammatory diseases [1, 27]. Second generation antifolates such as raltitrexed (ZD1694) and Alimta are registered for clinical use [28, 29].

In addition to MTX, also natural folates, such as folic acid and leucovorin, were identified as substrates of MRPs [24-26, 30]. Accordingly, many MRPs play a role in antifolate resistance and in controlling cellular homeostasis of natural folates [30].

The above-mentioned observation that folates enhance the MRP1-mediated efflux of DNR was ascribed to an induction of MRP1 transport activity, rather than to an increase in expression level of MRP1 [13]. This raised the question whether folate supplementation not only enhances MRP1 transport activity, but also induces MRP1-mediated cellular drug resistance to DNR and other anticancer agents.
In this study, we investigated whether folates provoke drug resistance to DNR and structurally unrelated MRP1 substrates. In addition, since DNR is a positively charged agent, we now also studied whether folates induce cellular efflux of negatively charged compounds.

\section{Materials and methods}

Reagents and cell lines

Folic acid, L-leucovorin (LV), verapamil (Vp), and digitonin were obtained from Sigma Chemical Co. (St. Louis, MO). Protease inhibitor cocktail was purchased from Boehringer, NL. Normal RPMI-1640 medium (which contains $2.3 \mu \mathrm{M}$ folic acid), folate-free RPMI-1640 medium, normal fetal calf serum, and dialyzed fetal calf serum were obtained from GIBCO (Grand Isl., NY). Daunorubicin HCL (DNR) was from Specia (Paris, France). Doxorubicin $\mathrm{HCl}(\mathrm{DOX})$ was obtained from Montedison Nederland (Rotterdam, the Netherlands). MTX was a gift from Pharmachemie (Haarlem, the Netherlands). Calcein-AM and the DNA probe Syto 13 were from Molecular Probes (Eugene, OR). The MRP1 inhibitor MK571 (L-660,711) was obtained from Dr. Robert Zamboni (Merck-Frost, Pointe-Claire, Quebec, Canada).

The human ovarian carcinoma cell line 2008wt, which expresses a basic level of MRP1, and its stable MRP1 transfectant 2008/MRP1 were kindly provided by Prof. Dr. P. Borst (The Netherlands Cancer Institute, Amsterdam). These cell lines were cultured in RPMI 1640 medium, supplemented with $10 \%$ FCS, $2 \mathrm{mM}$ glutamine, and $100 \mu \mathrm{g} / \mathrm{ml}$ penicillin/streptomycin. This culture medium is factory-supplied with $2.3 \mu \mathrm{M}$ folic acid. For folate deprivation, cells were cultured for 2 days in special folic acid-free RPMI 1640 medium supplemented with $10 \%$ dialyzed FCS, $2 \mathrm{mM}$ glutamine, and $100 \mu \mathrm{g} / \mathrm{ml}$ penicillin/ streptomycin.

\section{Growth inhibition}

Cells $\left(1 \times 10^{4}-1.75 \times 10^{4} /\right.$ well $)$ were seeded in $1 \mathrm{ml}$ of culture medium in 24 -well plates and cultured at $37{ }^{\circ} \mathrm{C}$. Cells were allowed to attach for $24 \mathrm{~h}$. Cells were then exposed to various concentrations of the drugs covering a three-log range for either $4 \mathrm{~h}$ (MTX) or $72 \mathrm{~h}$ (other drugs). Following the 4-h exposure to MTX, the medium was aspirated, and the cells were washed thrice with $2.5 \mathrm{ml}$ drug-free medium at $37{ }^{\circ} \mathrm{C}$. Thereafter, the cells were cultured for an additional $68 \mathrm{~h}$ at $37^{\circ} \mathrm{C}$. After $72 \mathrm{~h}$, cells were detached by trypsinization, and the cells were counted using a microcell counter. Finally, drug concentrations inhibiting $50 \%$ growth inhibition (IC50) were determined. 
Cellular calcein accumulation

Steady-state cellular accumulation of calcein was measured using a method described by Feller et al. [31] with several modifications. Cells were plated in a 96-wells plate at a density of 2000 cells/well, 1 day prior to the measurement. Cells were either cultured in folate-free or folate-rich medium (2.3 $\mu \mathrm{M}$ folic acid). The next day, all cells were exposed to $10 \mu \mathrm{M}$ calcein-AM for $30 \mathrm{~min}$. Thereafter, fluorescence of the formed calcein was measured in a fluorescence meter, type SpectraFluor (Tecan Austria Gmbh, Groedig, Austria). The maximal level of calcein accumulation was determined in control cells by adding $100 \mu \mathrm{M}$ of the MRP1 inhibitor MK-571 [32] 10 min prior to the calcein-AM exposure.

\section{Cellular drug efflux}

Efflux of fluorescent calcein was measured using an online computerized method described by Wielinga et al. [33]. In brief, cells were cultured on glass coverslips that fitted to the wall of a cuvette of $1 \times 1 \times 4 \mathrm{~cm}$ (width, depth, and height). To load the cells with substrate, the coverslips were placed in a petri dish containing culture medium $\left(37^{\circ} \mathrm{C}\right)$, $1 \mu \mathrm{M}$ calcein-AM, and $150 \mu \mathrm{M}$ Verapamil (to block MRP1-mediated efflux during the loading period) until steady state was reached ( $\geq 2 \mathrm{~h}$ ). After loading, the cells were put on ice until further use.

For an efflux experiment, a coverslip was washed twice with ice-cold medium A (RPMI medium without phenol red). The coverslip was placed in the cuvette that contained 3-ml warm $\left(37^{\circ} \mathrm{C}\right)$ medium A. The fluorescence of the effluxed substrate appearing in the medium was monitored with a spectrafluorometer (FluoroMax, SPEX Industries, Edison, NJ). Fluorescence of calcein was measured every second at excitations and emission wavelengths of 492 and $530 \mathrm{~nm}$, respectively. At the end of the experiment, $25 \mu \mathrm{M}$ digitonin was added to permeabilize the cells and to determine the total amount of intracellular DNR. Next, the cell number was determined by adding $400 \mathrm{nM}$ of the DNA probe Syto 13 . The DNR signals were normalized for the Syto 13 signals. The fluorescence of Syto 13 was determined at excitation wavelength of $485 \mathrm{~nm}$ and emission wavelength of $520 \mathrm{~nm}$.

\section{Nucleotide levels}

Extraction of nucleotides from cells was performed as described previously [34]. Subsequently, separation and quantification of the nucleotide pools were done using a gradient HPLC system consisting of two Gyncotek pumps (model 300, Separation Analytical Instruments BV, Hendrik Ido Ambacht, the Netherlands), as described earlier
[34]. The HPLC system was connected to a photo-diode array detector (Separations, model 1000S), regularly set at 254 and $280 \mathrm{~nm}$. Chromatography peaks were quantitated using the data acquisition program Chromeleon 3.02.

\section{Results}

Folate-rich cell culture conditions are associated with increased MRP1 transport activity and a decreased cellular accumulation of calcein proportional to MRP1 expression

In order to demonstrate that MRP1-mediated transport is controlled by the cellular folate status, we measured the cellular extrusion of the model MRP1 substrate calcein [31] in cells with a basic level of MRP1 expression (2008wt cells) and in MRP1-overexpressing cells (2008/MRP1 cells). Both cell lines were cultured either continuously in standard RPMI medium containing $2.3 \mu \mathrm{M}$ folic acid (folaterich), or for $48 \mathrm{~h}$ in folate-free medium. In folate-rich medium, the initial calcein efflux rate from 2008/MRP1 cells was up to fourfold faster compared with the efflux from 2008wt cells (Fig. 1). After folate depletion for $48 \mathrm{~h}$, the calcein efflux rate was about twofold decreased in the MRP1-transfected cells compared with folate-rich conditions. Also in the wild type cells, a significant reduction in calcein efflux (albeit smaller) could be observed.

We also examined the influence of cellular folate concentration on the steady-state accumulation of calcein in

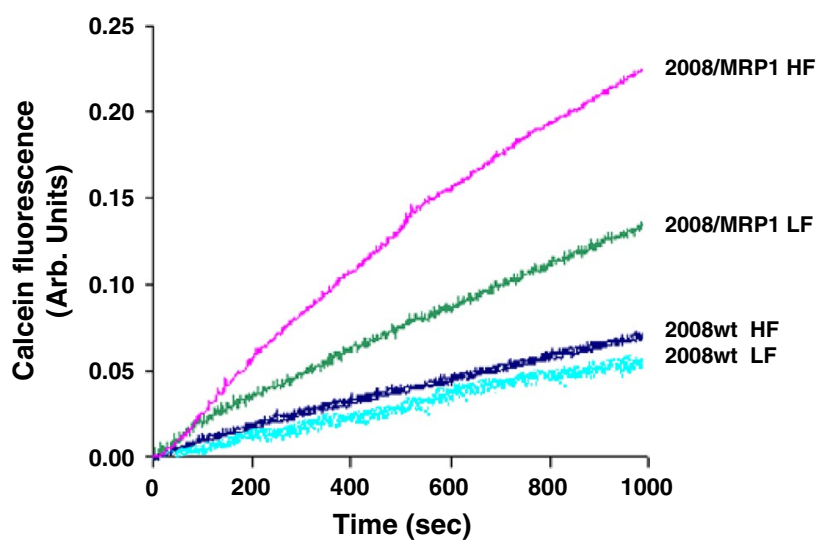

Fig. 1 MRP1-mediated efflux of calcein. Representative calcein efflux traces are shown for 2008wt cells and 2008/MRP1 cells. Cells were loaded with $1 \mu \mathrm{M}$ calcein-AM for $1 \mathrm{~h}$ in the presence of $150 \mu \mathrm{M}$ verapamil (to block MRP1 and non-MRP-mediated extrusion during the loading period) prior to the efflux experiment. Prior to the experiment cells were cultured for $48 \mathrm{~h}$ in either folate-free medium (LF, low-folate), or folate-rich medium (HF, high folate). The fluorescent signals are plotted after normalization with respect to the total amount of DNR in each experiment. SD between experiments $(n=3)$ was $<15 \%$ 


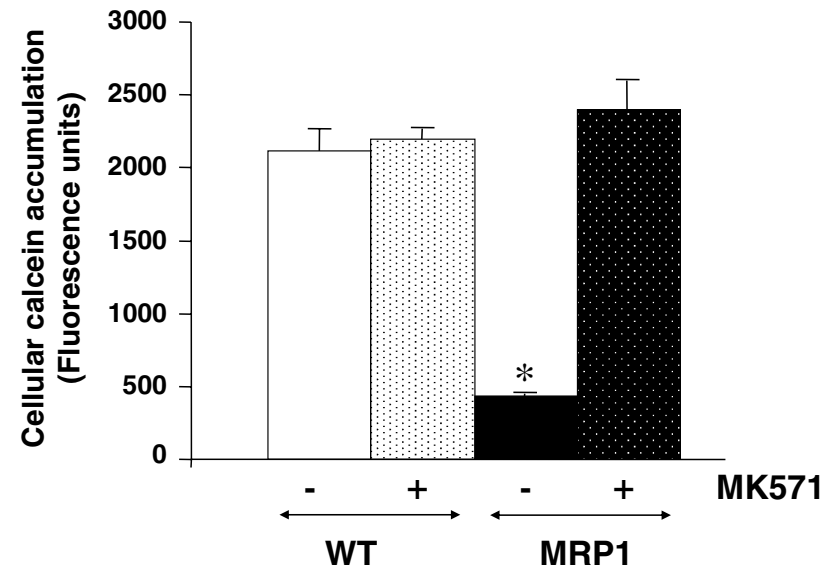

Fig. 2 Cellular accumulation of calcein in MRP1-overexpressing cells. Steady-state accumulation of calcein in 2008wt cells (indicated as WT) and 2008/MRP1 cells (indicated as MRP1) is shown. Cells were cultured in standard, folate-rich medium. To determine the maximal reachable calcein level, cells were exposed to the MRP1 inhibitor MK571 for $10 \mathrm{~min}$ prior to the loading of calcein (indicated with + in the figure). Fluorescent signals are given as Mean $\pm \mathrm{SD}$ $(n=3)$. Asterisk indicates a significant difference compared with the maximal reachable calcein level in the same cell line $(p<0.05)$

MRP1 expressing cells. In standard folate-rich culture medium, the cellular accumulation of calcein in MRP1overexpressing 2008/MRP1 cells was $23 \%$ of the calcein level in their wild type counterparts 2008wt (Fig. 2). Exposure to the MRP1 inhibitor MK571 completely equalized calcein accumulation between these two cell lines.

When cultured in folate-free medium for up to 10 days, the accumulation of calcein in 2008/MRP1 cells gradually increased fivefold (Fig. 3a). Although less, even in 2008wt cells, a significant increase in calcein accumulation could be observed after folate depletion (Fig. 3b).

In Fig. 4, the effect on cellular calcein accumulation of a 24-h exposure to L-leucovorin after a folate-free period is shown. In the MRP1-overexpressing cells, this short-term L-leucovorin supplementation resulted in a restored calcein level that was comparable to levels found in continuous folate-rich conditions (Fig. 4).

\section{Cellular nucleotide levels}

Because the MRP1-mediated efflux of its substrates is energy-dependent, we verified whether cellular ATP levels remained sufficient during folate-free culture conditions. During the first 7 days of folate depletion, no significant decrease in ATP or other nucleotides was observed. Over a 10 days culture period in folate-free medium, ATP levels gradually decreased to about half of those in both 2008wt and 2008/MRP1 cells (data not shown).
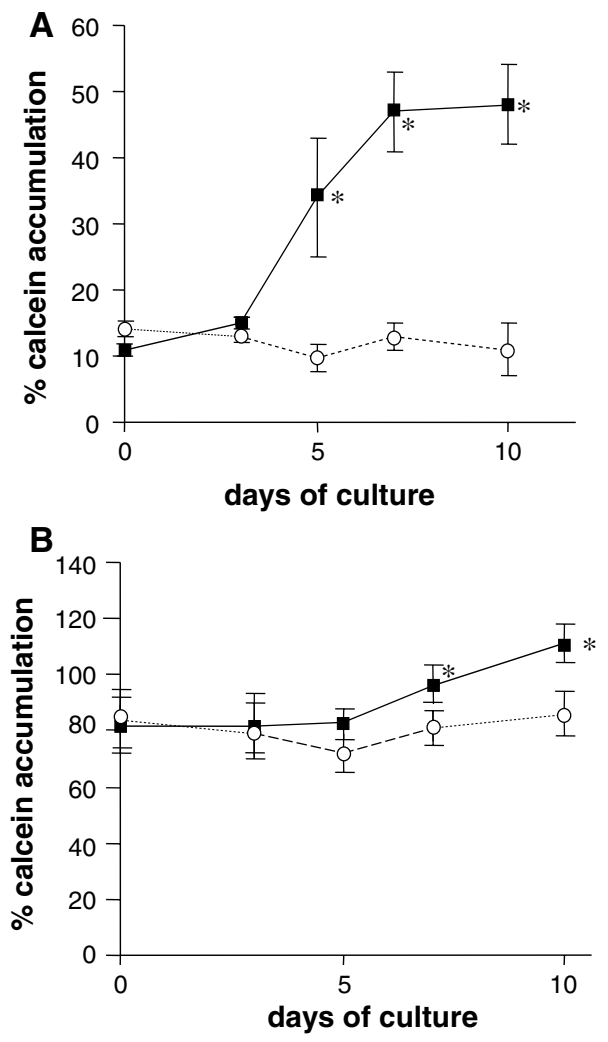

Fig. 3 Influence of folate depletion in time on cellular accumulation of calcein. Cells were cultured for 0-10 days in either folate-rich medium (white dots) or folate-free medium (black squares). At days $3,5,7$, and 10 , cellular calcein accumulation was measured as in Fig. 2. a The influence of folate concentration in 2008/MRP1 cells, and $\mathbf{b}$ in 2008wt cells. Fluorescent signals are given as Mean \pm SD $(n=4)$. Asterisk indicates a significant difference compared with folate-rich conditions $(P<0.05)$

Increased folate concentration enhances MRP1-mediated drug resistance

As shown above, the cellular folate concentration is a determining factor in the transport activity of MRP1. It might therefore impact MRP1-mediated MDR. In order to study this, we performed growth inhibition experiments under different cellular folate conditions using the anthracyclines DNR, and DOX, as well as MTX, vincristine and etoposide. All these agents are established MRP1 substrates. The IC50 values for these drugs were determined in 2008wt and 2008/MRP1 cells that were cultured in either folic acidfree medium or in folate-rich medium for 3 days. To prevent polyglutamylation of MTX, which promotes cellular retention, exposure time for this drug was $4 \mathrm{~h}$, followed by 3-day drug-free culture.

Under folate-rich conditions, the 2008/MRP1 cells were highly resistant against all drugs compared with the 2008wt cells (Fig. 5). Resistance factors were 5.8-fold (DOX), 3.8-fold (DNR), and 21.0-fold (MTX). When cultured in 


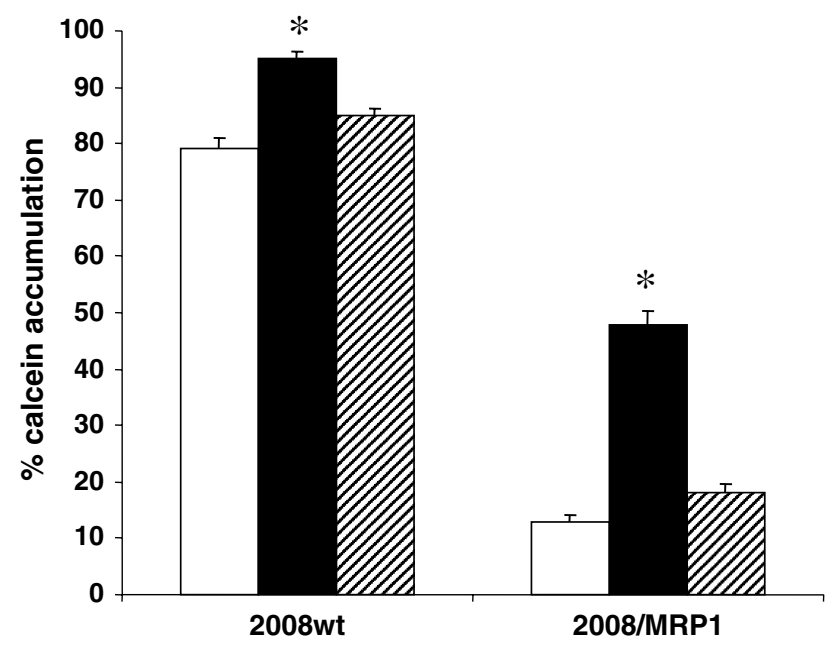

Fig. 4 Effect of L-leucovorin supplementation of cellular accumulation of calcein in MRP1-overexpressing cells. Accumulation of $1 \mu \mathrm{M}$ calcein in 2008wt cells and 2008/MRP1 cells was determined as in Figs. 2 and 3. Cells were cultured for 7 days in folaterich medium (white bars), in folate-free medium (black bars), or in folate-free medium followed by a 24-h exposure to $2.3 \mu \mathrm{M}$ L-leucovorin (hatched bars). Fluorescent signals are given as Mean \pm SEM $(n=3)$. Asterisk indicates a significant difference compared with folate-rich conditions in the same cell line $(P<0.05)$

folate-free medium, however, the IC50 values for DOX and MTX were markedly lower in the MRP1-overexpressing cells (fivefold, and 83-fold, respectively). For DNR, a smaller but significant decrease was observed. For vincristine and etoposide, however, toxicity was hardly affected by folate condition in 2008wt and 2008/MRP1 cells (data not shown).

\section{Discussion}

Folate supplementation is part of in several routine chemotherapy protocols to reduce drug toxicity $[9,10]$. It also was reported as a strategy to increase antitumor activity $[11,12]$.

In recent years, it became clear that folates also interact with $\mathrm{ABC}$ transporter proteins that play a role in MDR. Folic acid and leucovorin are, for instance, substrates of MRP1 and its homologs [24-26, 30]. However, the fact that many MDR pumps harbor the capacity to transport folates does not automatically imply that folates act as competitive inhibitors in MDR. We demonstrated in an earlier study that high cellular folate concentrations induce MRP1-mediated cellular efflux of the positively charged drug DNR [13]. Notably, two-day culture in folate-free medium decreased the total cellular DNR efflux to $43 \%$ in 2008/MRP1 cells and to $84 \%$ in 2008wt cells. Repletion of folate by a $2-24-h$ exposure completely restored of DNR
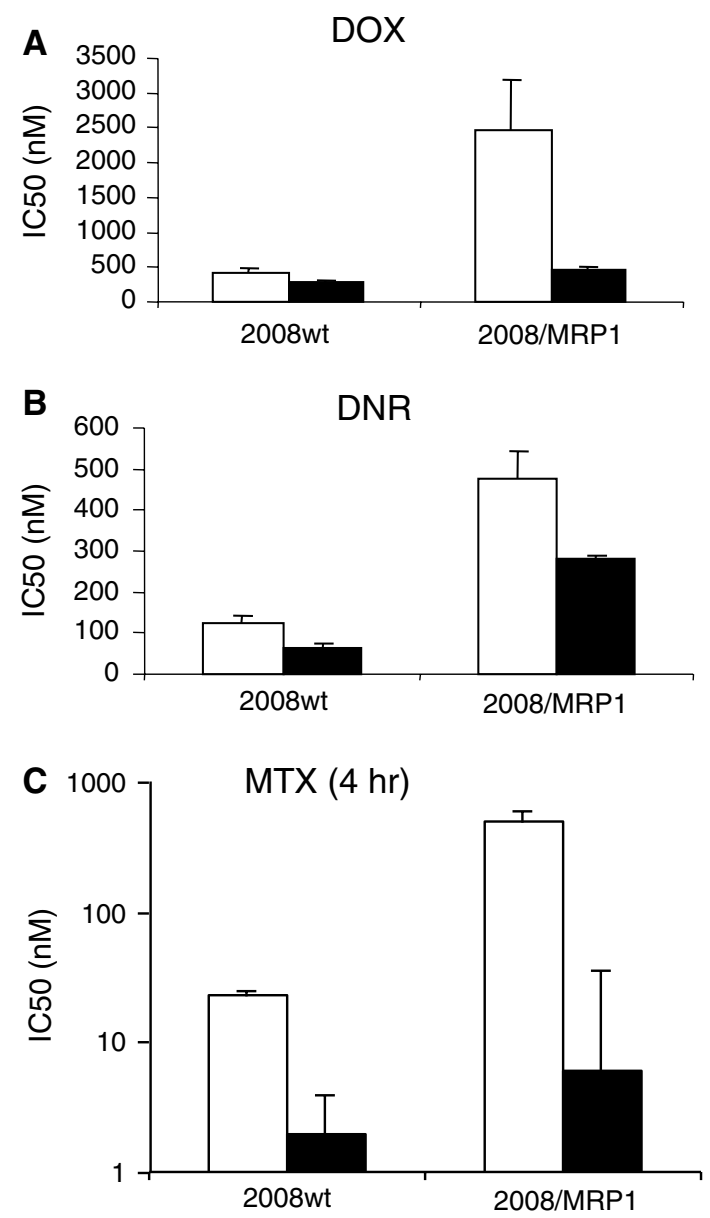

Fig. 5 Influence of folate concentration on MRP1-associated drug resistance. Growth inhibition by doxorubicin (DOX), daunorubicin (DNR), and methotrexate (MTX) was determined in 2008wt cells and 2008/MRP1 cells. IC50s for each drug were determined for a 3-day culture in either folate-rich medium (white bars), or in folate-free medium (black bars). During this period, drugs were continuously present, except for MTX. The latter was present during the first $4 \mathrm{~h}$ and subsequently washed away in order to prevent polyglutamylation of MTX. IC50s are given as Mean $\pm \operatorname{SD}(n=5)$

efflux in these cells. Based on these observations, we then postulated that folates apparently interact with MRP1 in a similar way as gluthathione (GSH) [35].

GSH is crucial for MRP1-mediated transport of positively charged compounds like DNR and DOX. Several studies debated on the exact role of GSH in MRP1 activity $[36,37]$. GSH was described as a co-substrate in transport of positively charged drugs [36] and/or to form a conjugate with positively charged drugs [37]. Similarly, GSH and its non-reducing alkyl derivative S-methyl GSH were shown to stimulate MRP1 transport activity of endogenous compounds, rather than act as co-substrates or conjugates [38]. As proposed by Borst et al. [39], the glutamate residue of GSH could be important in the binding to a reactive site in the MRP1 protein. Like GSH, also folates contain 
a glutamate residue that might play a key role in its interaction with MRPs. In this present study, we showed that basal efflux of the negatively charged compound calcein by MRP1 is enhanced by folates. Calcein is not dependent on GSH for its transport by MRP1 [31]. Although this contradicts an exact identical role for folates and GSH in MRP1 activity, it does support the postulation that MRP1 activity is subject to various modes of modulation.

Other mechanisms through which folates might influence MRP1 transport activity are open for consideration. A decrease in cellular ATP levels as a result of altered cellular folate status was excluded in our study as a possible cause of decreased MRP1 activity. Increments of cellular homocysteine levels as a result of lowered folate status were reported [35], but whether these influence MRP1 function is not clear. Finally, the cellular folate status can influence indirectly the regulation of gene expression through methylation of $\mathrm{CpG}$ islands in the promoter region of a variety of genes $[40,41]$. However, as we reported earlier, short folate depletion periods $(<10$ days) did not impact the expression level of MRP1 protein [13]. Reports of loss of MRP1 expression upon prolonged ( $>3$ months) folate deprivation [42] were probably due to a selection process, in which a decreased MRP1 expression is physiologically beneficial to withhold intracellular folates under folate-restricted conditions.

An important issue is whether our "proof-of-principle" experiments in this study can be translated to MDR phenomena in patients. First, folate levels in human plasma, in normal human tissues, and in solid tumors normally vary between 5 and $20 \mathrm{nM} 5$-methyltetrahydrofolate [12, $43,44]$. These are approximately mimicked in the folatedeprived cells in vitro. In contrast, the "folate-rich" concentrations used in our study were supraphysiological and would only represent cases of extreme folate oversupplementation. Secondly, in the present study, we focused primarily on MRP1. Conceivably, however, in MDR, a much broader range of MRP1 homologs as well as other ABC transporter proteins may contribute, including BCRP and Pgp. The dynamic interplay between all of these transporters in a diversity of tissues and cell types has to be taken into account to fully understand the complete role of folates in MDR. Expanding this study to other ABC transporters and clinically relevant physiological folate supplementation levels would merit further exploration.

In conclusion, folate supplementation during chemotherapy may have several impacts: reduction in toxicity, increase in antitumor activity, but also induction of MRP1 transport activity and cellular drug resistance. These latter effects of folate intake and folate levels during chemotherapy deserve ongoing considerations.

Acknowledgments This study was supported by the Dutch Cancer Society (Grant NKB-VU 2000-2237).
Conflict of interest The authors declare no financial and personal relationship with other people or organizations that inappropriately influence our work.

\section{References}

1. Bertino JR (1993) Ode to methotrexate. J Clin Oncol 11:5-14

2. Choi SW, Mason JB (2000) Folate and carcinogenesis: an integrated scheme. J Nutr 130:129-132

3. Molloy AM, Scott JM (2001) Folates and prevention of disease. Public Health Nutr 4(2B):601-609

4. Kim YI (2003) Role of folate in colon cancer development and progression. J Nutr 133(Suppl 1):3731S-3739S

5. Mason JB (2011) Unraveling the complex relationship between folate and cancer risk. BioFactors 37:253-260

6. Weggemans RM, Schaafsma G, Kromhout D, Health Council of the Netherlands (2009) Toward an optimal use of folic acid: an advisory report of the Health Council of the Netherlands. Eur J Clin Nutr 63:1034-1036

7. Vollset SE, Clarke R, Lewington S, Ebbing M, Halsey J, Lonn E, Armitage J, Manson JE, Hankey GJ, Spence JD, Galan P, Bønaa KH, Jamison R, Gaziano JM, Guarino P, Baron JA, Logan RF, Giovannucci EL, den Heijer M, Ueland PM, Bennett D, Collins R, Peto R (2013) Effects of folic acid supplementation on overall and site-specific cancer incidence during the randomised trials: metaanalyses of data on 50.000 individuals. Lancet 381:1029-1036

8. Qin X, Cui Y, Shen L, Sun N, Zhang Y, Li J, Xu X, Wang B, Xu X, Huo Y, Wang X (2013) Folic acid supplementation and cancer risk: a meta-analysis of randomized controlled trials. Int J Cancer 133:1033-1041

9. Bertino JR (1977) "Rescue" techniques in cancer chemotherapy: use of leucovorin and other rescue agents after methotrexate treatment. Semin Oncol 4(sup2):203-216

10. Zervos PH, Allen RH, Thornton DE, Thiem PA (1997) Functional folate status as a prognostic indicator of toxicity in clinical trials of the multitargeted antifolate LY231514. Eur J Cancer (suppl) 33:S18

11. Vogelzang NJ, Rusthoven JJ, Symanowski J, Denham C, Kaukel E, Ruffie P, Gatzemeier U, Boyer M, Emri S, Manegold C, Niyikiza C, Paoletti P (2003) Phase III study of pemetrexed in combination with cisplatin versus cisplatin alone in patients with malignant pleural mesothelioma. J Clin Oncol 21:2636-2644

12. Porcelli L, Assaraf YG, Azzariti A, Paradiso A, Jansen G, Peters GJ (2011) The impact of folate status on the efficacy of colorectal cancer treatment. Curr Drug Metab 12:975-984

13. Hooijberg JH, Jansen G, Assaraf YG, Kathmann I, Pieters R, Laan AC, Veerman AJP, Kaspers GJ, Peters GJ (2004) Folate concentration dependent transport activity of the Multidrug Resistance Protein 1 (ABCC1). Biochem Pharmacol 67:1541-1548

14. Cole SP, Bhardwaj G, Gerlach J, Mackie JE, Grant CE, Almquist KC, Stewart AJ, Kurz EU, Duncan AM, Deeley RG (1992) Overexpression of a transporter gene in a multidrug-resistant human lung cancer cell line. Science 258:1650-1654

15. Borst P, Evers R, Kool M, Wijnholds J (2000) A family of drug transporters: the multidrug resistance-associated proteins. J Natl Cancer Inst 92:1295-1302

16. Borst P, Elferink RO (2002) Mammalian ABC transporters in health and disease. Annu Rev Biochem 71:537-592

17. Scotto KW (2003) Transcriptional regulation of ABC drug transporters. Oncogene 20(22):7496-74511

18. Kruh GD, Belinsky MG (2003) The MRP family of drug efflux pumps. Oncogene 20(22):7537-7552

19. Dean M, Allikmets R (2001) Complete characterization of the human ABC gene family. J Bioenerg Biomembr 33:475-479 
20. Hooijberg JH, Broxterman HJ, Kool M, Assaraf YG, Peters GJ, Noordhuis P, Scheper RJ, Borst P, Pinedo HM, Jansen G (1999) Antifolate resistance mediated by the multidrug resistance proteins MRP1 and MRP2. Cancer Res 59:2532-2535

21. Chen ZS, Tiwari AK (2011) Multidrug resistance proteins (MRPs/ABCCs) in cancer chemotherapy and genetic diseases. FEBS J 278:3226-3245

22. Cole SP (2014) Targeting Multidrug Resistance Protein 1 (MRP1, ABCC1): past, present, and future. Annu Rev Pharmacol Toxicol $54: 95-117$

23. Kool M, Van der Linden M, De Haas M, Scheffer GL, De Vree ML, Smith AJ, Jansen G, Peters GJ, Ponne N, Scheper RJ, Oude Elferink RPV, Baas F, Borst P (1999) MRP3, a new organic anion transporter able to transport anti-cancer drugs. Proc Natl Acad Sci USA 96:6914-6918

24. Zeng H, Chen ZS, Belinsky MG, Rea PA, Kruh GD (2001) Transport of methotrexate (MTX) and folates by Multidrug Resistance Protein (MRP) 3 and MRP1: effect of poly-glutamylation on MTX transport. Cancer Res 61:7225-7232

25. Lee K, Klein-Szanto AJ, Kruh GD (2000) Analysis of the MRP4 drug resistance profile in transfected NIH3T3 cells. J Natl Cancer Inst 92:1934-1940

26. Chen ZS, Lee K, Walther S, Blanchard R, Kuwano M, Zeng H, Kruh GD (2002) Analysis of methotrexate and folate transport by Multidrug Resistance Protein 4 (ABCC4): MRP4 is a component of the methotrexate efflux system. Cancer Res 62:3144-3150

27. Cronstein BN (1996) Methotrexate and its mechanism of action. Arthritis Rheum 39:1951-1960

28. Purcell WT, Ettinger DS (2003) Novel antifolate drugs. Curr Oncol Rep 5:114-125

29. Zhao R, Goldman ID (2003) Resistance to antifolates. Oncogene 22:7431-7457

30. Hooijberg JH, Peters GJ, Assaraf YG, Kathmann I, Priest DG, Bunni MA, Veerman AJ, Scheffer GL, Kaspers GJ, Jansen G (2003) The role of multidrug resistance proteins MRP1, MRP2 and MRP3 in cellular folate homeostasis. Biochem Pharmacol 65:765-771

31. Feller N, Broxterman HJ, Wahrer DC, Pinedo HM (1995) ATPdependent efflux of calcein by the multidrug resistance protein (MRP): no inhibition by intracellular glutathione depletion. FEBS Lett 368:385-388

32. Gekeler V, Ise W, Sanders KH, Ulrich WR, Beck J (1995) The leukotriene LTD4 receptor antagonist MK571 specifically modulates MRP associated multidrug resistance. Biochem Biophys Res Commun 208:345-352
33. Wielinga PR, Heijn M, Westerhoff HV, Lankelma J (1998) A method for studying plasma membrane transport with intact cells using computerized fluorometry. Anal Biochem 263:221-231

34. Ruiz van Haperen VWT, Veerman G, Boven E, Noordhuis P, Vermorken JB, Peters GJ (1994) Schedule dependence of sensitivity to $2^{\prime}$,2-difluorocytidine (gemcitabine) in relation to accumulation and retention of its triphosphate in solid tumor cell lines and solid tumors. Biochem Pharmacol 48:1327-1339

35. Peters GJ, Kathmann I, Lemos C, Hooijberg JH, Losekoot N, Jansen G (2013) Folate homeostasis of cancer cells affects sensitivity to not only antifolates but also other non-folate drugs: effect of MRP expression. Pteridines 24:81-86

36. Loe DW, Deeley RG and Cole SP (1998) Characterization of vincristine transport by the Mw 190,000 kD Multidrug resistance protein (MRP): evidence for cotransport with reduced glutathione. Cancer Res 58:5130-5136

37. Jedlitschky G, Leier I, Buchholz U, Barnouin K, Kurz G, Keppler D (1996) Transport of glutathione, glucuronate, and sulfate conjugates by the MRP gene-encoded conjugate export pump. Cancer Res 56:988-994

38. Qian YM, Song WC, Cui H, Cole SP, Deeley RG (2001) Glutathione stimulates sulfated estrogen transport by Multidrug Resistance Protein 1. J Biol Chem 276:6404-6411

39. Borst P, Evers R, Kool M, Wijnholds J (1999) The Multidrug Resistance Protein Family. Biochem Biophys Acta 1461:347-357

40. Jhaveri MS, Wagner C, Trepel JB (2001) Impact of extracellular folate levels on global gene expression. Mol Pharmacol 60:1288-1295

41. Zingg JM, Jones PA (1997) Genetic and epigenetic aspects of DNA methylation on genome expression, evolution, mutation and carcinogenesis. Carcinogenesis 18:869-882

42. Assaraf YG, Rothem L, Hooijberg JH, Stark M, Ifergan I, Kathmann I, Dijkmans BA, Peters GJ, Jansen G (2003) Loss of multidrug resistance protein 1 expression and folate efflux activity results in a highly concentrative folate transport in human leukemia cells. J Biol Chem 278:6680-6686

43. Priest DG, Schmitz JC, Bunni MA, Stuart RK (1991) Pharmacokinetics of leucovorin metabolites in human plasma as a function of dose administered orally and intravenously. J Natl Cancer Inst 83:1806-1812

44. Choumenkovitch SF, Selhub J, Wilson PWF, Rader JI, Rosenberg IH, Jacques PF (2002) Folic acid intake from fortification in United States exceeds predictions. J Nutr 132:2792-2798 